\begin{tabular}{|c|c|c|}
\hline 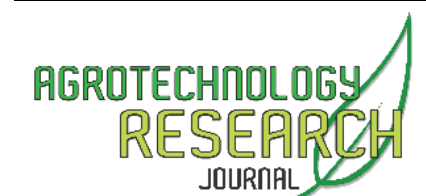 & $\begin{array}{c}\text { Agrotech Res J, June } 2019,3(1): 50-55 \\
\text { AGROTECHNOLOGY RESEARCH } \\
\text { JOURNAL }\end{array}$ & $\begin{array}{l}\text { ISSN 2655-7924 (Print) } \\
\text { ISSN 2614-7416 (Online) } \\
\text { https://jurnal.uns.ac.id/arj } \\
\text { doi: } 10.20961 / \text { agrotechresj.v3i1.27596 }\end{array}$ \\
\hline
\end{tabular}

\title{
Keberadaan Mikovirus Berdasarkan Deteksi Berbasis RNA pada Colletotrichum Hipovirulen
}

\author{
Lulu'il Maknun ${ }^{1}$, Supyani $^{*}$, Hadiwiyono ${ }^{3}$, Budi Tjahjono ${ }^{4}$ \\ 1-3Department of Agrotechnology, Faculty of Agriculture, Universitas Sebelas Maret, Surakarta, Indonesia \\ ${ }^{4}$ Department of Research and Development PT. Arara Abadi, Sinarmas Forestry, Siak, Indonesia
}

${ }^{*}$ Corresponding Author:

E-mail: supyani_id@yahoo.com

Received 4 February 2019; Accepted 31 May 2019; Published 30 June 2019

\begin{abstract}
Colletotrichum is one of phytopathogenic fungi causing large economic losses in more than 3000 plant species in the world. Colletotrichum causes anthracnose disease with sunken and concentric ring-shaped of necrosis symptoms on leaves and fruits. Chilli production has reported to have yield losses $10 \%-80 \%$ and production of Acacia spp. experiencing losses at the nursery stage due to anthracnose. Mycovirus is a biological control agent that has potential to develop through its hypovirulence effect generated on host pathogenic fungi. Mycovirus infect host fungi and replicate rapidly in host cells also can be transmitted through horizontal and vertical transmission. This research was purposed to detect the existence of mycoviruses in hypovirulent Colletotrichum. Stages of this research comprised Colletotrichum isolation, colony morphological observation, virulence assay on apples fruit, and RNA analysis included RNA extraction based on PrestoTM Mini RNA Yeast Kit protocol and RNA visualization on agarose gel using UV transilluminator. The results of RNA visualization showed the existence of specific RNA bands outside rRNA and tRNA bands in D3 and D9 isolates which were considered as RNA bands of mycovirus. The specific RNA bands in D3 isolate sized around $2 \mathrm{kbp}$ and $3 \mathrm{kbp}$ while D9 isolate showed specific RNA bands sized around $0.6 \mathrm{kbp}$ and $3 \mathrm{kbp}$.
\end{abstract}

(C) 2019 Agrotechnology Research Journal

Keywords Hypovirulence; RNA Mycovirus; Virocontrol; Mycophage; Anthracnose

Cite This As: Maknun L, Supyani, Hadiwiyono, Tjahjono B. 2019. Keberadaan Mikovirus Berdasarkan Deteksi

Berbasis RNA pada Colletotrichum Hipovirulen. Agrotech Res J 3(1):50-55.

https://doi.org/10.20961/agrotechresj.v3i1.27596

\section{PENDAHULUAN}

Colletotrichum merupakan salah satu kelompok patogen tanaman penting yang menyebabkan kerugian ekonomi yang besar di daerah tropis dan subtropis (Sakinah et al. 2014). Colletotrichum menyebabkan penyakit antraknosa pada lebih dari 3200 spesies monokotil dan dikotil. Infeksi jamur patogen ini juga menyebabkan kerugian pasca panen hingga 100\% (Campo et al. 2016). Colletotrichum merupakan patogen tular biji yang dapat bertahan di tanah (Sahitya et al. 2014). Penyebaran Colletotrichum didukung oleh kondisi basah, hangat, percikan hujan, dan angin yang lembab (Sharma dan Kulshrestha 2015).

Penelitian Saxena et al. (2016) melaporkan bahwa penurunan produksi cabai terbesar disebabkan oleh penyakit antraknosa atau busuk buah. Cabai yang terinfeksi Colletotrichum mengalami kerugian hasil

This is an open access article

Licensed under the Creative Commons Attribution International License CC-BY-NC 4.0

(c)) BY-NC mencapai 65\% (Salim 2012). Antraknosa menyebabkan kerusakan pada buah yang matang berupa busuk buah berbentuk jaringan nekrosis cekung dengan cincin konsentris, baik di lapang maupun di dalam penyimpanan dengan kondisi yang baik (Saxena et al. 2016). Gejala lain yang muncul pada tanaman tahunan seperti Acacia spp. berupa nekrosis pada ujung daun dan bercak daun (Thu et al. 2010). Kerugian yang besar terjadi akibat serangan ketika pembibitan bahkan mengakibatkan kematian pada bibit.

Pengendalian patogen Colletotrichum spp. perlu dilakukan untuk mengurangi kerugian hasil tanaman.

Pengendalian hayati merupakan salah satu teknik pengendalian yang berpotensi untuk dikembangkan dengan memanfaatkan agens hayati. Oo dan Oh (2016), menjelaskan bahwa teknik pengendalian hayati merupakan solusi untuk mengatasi efek negatif dari pengendalian secara kimia. Pengendalian hayati lebih dipilih karena ramah lingkungan dan tidak menimbulkan residu berbahaya (Soesanto 2013).

Pemanfaatan mikovirus merupakan salah satu alternatif pengendalian hayati yang potensial. Mikovirus 
dapat menginfeksi jamur fitopatogen dan melemahkan virulensinya. Mikovirus dapat bereplikasi dengan cepat di dalam sel jamur fitopatogen (Kumar dan Chandel 2016). Hipovirulensi akibat infeksi mikovirus dapat ditularkan ke jamur lain yang kompatibel melalui transmisi mikovirus secara vertikal dengan sporulasi dan horizontal dengan anastomosis hifa dan pembelahan sel (Wang et al. 2017).

Cryphonectria hipovirus 1 (CHV1) merupakan contoh virus jamur terkait hipovirulensi yang berhasil digunakan untuk mengendalikan penyakit hawar kastanye di Eropa (Ghabrial et al. 2015). Rosellinia necatrix megabirnavirus 1 dari jamur busuk akar putih Rosellinia necatrix juga menunjukkan potensi signifikan sebagai kontrol biologis (Yu et al. 2013). CcFV-1 (Colletotrichum camelliae filamentous virus 1) merupakan mikovirus yang ditemukan pada Colletotrichum camelliae yang dapat merusak homeostasis seluler inang, menyebabkan hipovirulensi, dan mempengaruhi morfologi inang seperti produksi dan distribusi pigmen, laju pertumbuhan, dan pembentukan cincin hifa (Jia et al. 2017).

Eksplorasi mikovirus di Indonesia telah mulai dirintis namun belum banyak dilakukan (Supyani 2017). Penelitian ini bertujuan mendeteksi keberadaan mikovirus pada Colletotrichum hipovirulen. Sebanyak 14 isolat hipovirulen dari total 36 isolat Colletotrichum dilakukan deteksi RNA untuk mendeteksi keberadaan RNA mikovirus. Upaya tersebut dilakukan sebagai tahapan awal dalam pengembangan mikovirus sebagai kandidat agens pengendalian hayati Colletotrichum virulen.

\section{BAHAN DAN METODE}

Penelitian dilaksanakan pada Februari sampai September 2018 di Laboratorium Pathology dan Ruang PCR, Plant Protection Department, R\&D PT. Arara Abadi, Sinarmas Forestry, Riau. Tahapan dalam penelitian ini terdiri dari isolasi Colletotrichum, pengamatan morfologi koloni, uji virulensi, dan analisis RNA. Colletotrichum diisolasi dari buah cabai asal Bukittinggi dan daun Acacia mangium asal Palembang yang bergejala antraknosa.

Isolasi Colletotrichum dilakukan dengan memotong buah dan daun sebesar $5 \times 5 \mathrm{~mm}$ pada sebagian jaringan bergejala antraknosa dan sebagian jaringan yang sehat. Bagian yang telah dipotong disterilisasi dengan direndam clorox selama 2 menit kemudian dibilas dengan air steril sebanyak dua kali (Photita et al. 2005). Potongan buah dan daun selanjutnya dikeringkan di atas tisu steril. Potongan yang sudah kering dikulturkan pada PSA sebanyak dua ulangan dan diinkubasi dalam inkubator dengan suhu $\pm 26^{\circ} \mathrm{C}$ selama 7 hari. Isolat yang tumbuh diseleksi berdasarkan karakter Colletotrichum untuk disubkultur menjadi isolat murni.

Pengamatan morfologi koloni dilaksanakan dengan mengkulturkan miselia Colletotrichum pada PSA dengan satu titik tepat di tengah cawan petri berdiameter $9 \mathrm{~cm}$. Setiap kode isolat dikultur sebanyak tiga ulangan selanjutnya diinkubasi dalam inkubator dengan suhu $\pm 26^{\circ} \mathrm{C}$. Pengamatan diameter koloni dan karakter morfologi koloni dilakukan setelah 7 hari inkubasi (Sakinah et al. 2014). Pengamatan karakter morfologi meliputi pigmentasi, bentuk, tepian, tekstur, elevasi, dan opasitas.

Uji virulensi dilakukan pada buah apel hijau (Granny Smith) yang dicuci dengan air dan sabun untuk menghilangkan lapisan lilin kemudian disemprot alkohol $70 \%$ dan diusap. Buah apel dilubangi menggunakan cork borer sedalam $5 \mathrm{~mm}$ sebanyak empat titik lubang inokulasi dengan posisi menyebar seimbang. Tiga lubang diinokulasi isolat Colletotrichum dengan kode yang berbeda secara acak dan satu lubang tidak diinokulasi (kontrol). Setiap kode isolat memiliki tiga ulangan yang terletak pada tiga buah apel yang berbeda. Posisi inokulum dihadapkan pada jaringan dan ditekan dengan jarum ose sampai terjadi kontak dengan jaringan buah apel. Lubang ditutup dengan lakban bening. Buah apel diinkubasi di dalam inkubator dengan suhu $\pm 26^{\circ} \mathrm{C}$. Diameter lesio diamati pada hari ke 14 setelah inokulasi.

Analisis RNA meliputi ekstraksi dan visualisasi RNA. Miselia Colletotrichum diekstraksi berdasarkan protokol Presto $^{T M}$ Mini RNA Yeast Kit. Sampel RNA yang telah diekstraksi dan loading dye dicampur dengan perbandingan 12:3 $\mu \mathrm{L}$ kemudian dipindah ke dalam sumuran gel agarose $1 \%$ yang direndam TAE DEPC $1 \mathrm{x}$. Marker 100 bp DNA ladder ditambahkan pada salah satu sumuran sebanyak $3 \mu \mathrm{L}$. RNA dielektroforesis selama 25 menit dengan tegangan 100 volt. RNA hasil elektroforesis divisualisasi menggunakan UV Transilluminator. Peubah yang diamati adalah keberadaan RNA mikovirus ketika visualisasi RNA total. Pita RNA yang muncul selain rRNA dan tRNA merupakan RNA asing yang dapat diduga sebagai genom mikovirus.

\section{HASIL DAN PEMBAHASAN}

Isolat Colletotrichum yang digunakan pada penelitian ini memiliki karakter koloni yang beragam. Hasil pengamatan morfologi koloni 36 isolat Colletotrichum menunjukkan pengelompokan isolat menjadi tiga grup berdasarkan warna koloninya (Gambar 1). Pengelompokan tersebut terdiri dari 13 isolat berwarna abu-abu kehijauan, 13 isolat berwarna jingga, dan 10 isolat berwarna putih.

Isolat dengan warna koloni abu-abu kehijauan adalah isolat yang berasal dari daun $A$. mangium. Kebanyakan isolat yang diisolasi dari buah cabai asal Bukittinggi memiliki warna koloni jingga sedangkan isolat yang diisolasi dari buah cabai asal Boyolali dan Karanganyar kebanyakan memiliki warna koloni putih. Morfologi koloni Colletotrichum bervariasi di dalam maupun diantara kelompoknya berdasarkan media kulturnya, substrat dan suhu, dan faktor-faktor lain (Contreras 2006, Martinez et al. 2009). 


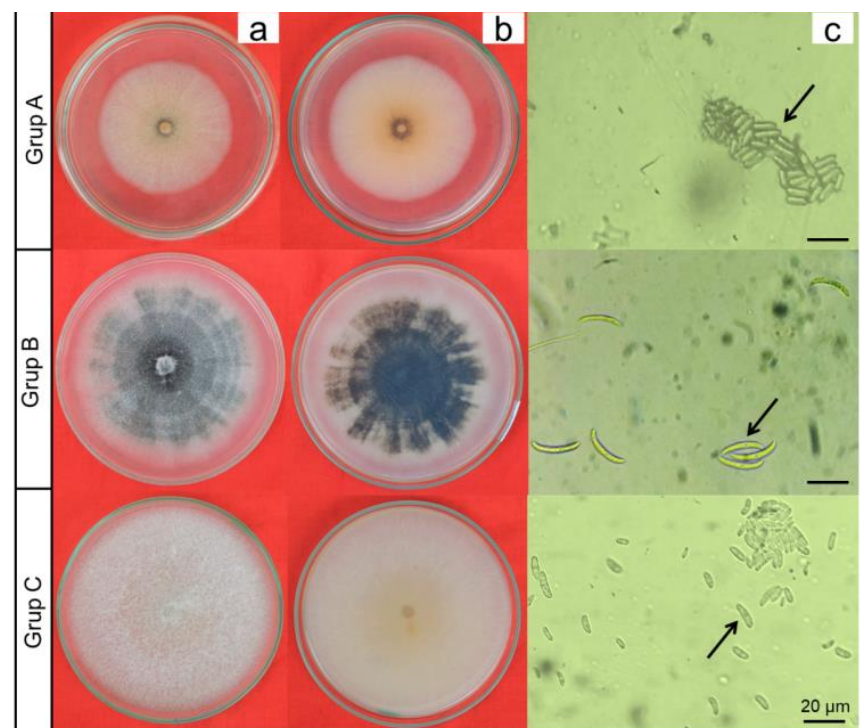

Gambar 1. Koloni Colletotrichum yang ditumbuhkan pada PSA selama 7 hari: grup A berwarna jingga, grup B berwarna abu-abu kehijauan, grup $C$ berwarna putih, (a) tampilan atas koloni pada PSA, (b) tampilan bawah koloni pada PSA, dan (c) hasil pengamatan mikroskopis konidia Colletotrichum spp.

Grup A secara umum memiliki koloni berwarna jingga dengan tekstur halus, tepian siliat, elevasi timbul, dan opasitas buram. Konidia dari grup A memiliki kemiripan seperti $C$. gloeosporioides yaitu uniseluler, hialin, lurus, berbentuk silindris dan bulat di ujung atau sedikit sempit di salah satu ujung (Kim et al. 2009) serta koloninya berwarna jingga pucat hingga pink-jingga (Weir et al. 2012). Grup A meliputi isolat dengan kode C2-C13, 179C, dan B1.16.

Grup B cenderung memiliki koloni berwarna abu-abu kehijauan dengan bentuk koloni konsentris, tepian siliat, tekstur kasar, elevasi seperti tombol, dan opasitas buram. Grup B memiliki kemiripan sifat dengan $C$. capsici yang memiliki bentuk konidia memanjang dengan ujung meruncing berbentuk sabit (falcate) serta warna koloni putih hingga abu-abu dengan hijau gelap di bagian tengahnya (Than et al. 2008). Grup B meliputi isolat dengan kode 178C, 183C, C1, dan D1-D10.

Grup C secara umum memiliki warna koloni putih dengan bentuk koloni bundar, tepian siliat, tekstur kasar, elevasi timbul, dan opasitas buram. Karakteristik grup C cenderung mirip pada $C$. acutatum dengan konidia bersifat uniseluler, hialin, lurus, berbentuk fusiform dan meruncing di setiap ujungnya (Kim et al. 2009) serta warna koloni krem hingga putih (Abera et al. 2016). Grup C meliputi B1.4, B1.11, B1.14, B1.17, K1.2, K1.3, K1.5, $\mathrm{K} 1.6$, dan K1.7. Ciri-ciri umum jamur dari genus Colletotrichum yaitu memiliki hifa bersekat dan bercabang serta menghasilkan konidia yang transparan dan memanjang dengan ujung meruncing (Dickman 1993).

Perbedaan warna koloni isolat Colletotrichum memiliki hubungan dengan virulensinya. Berdasarkan uji virulensi pada buah apel, isolat dengan koloni berwarna jingga dan putih cenderung memiliki virulensi sedang hingga tinggi. Koloni isolat dengan warna abu-abu kehijauan cenderung memiliki virulensi rendah atau hipovirulen (Gambar 2).

Karakter morfologi juga diamati berdasarkan pertumbuhan diameter koloninya. Data pertumbuhan koloni 36 isolat Colletotrichum ditunjukkan oleh diameter koloni yang ditumbuhkan pada PSA selama 7 hari. Hasil analisis korelasi antara rata-rata diameter koloni in vitro dan rata-rata diameter lesio pada apel memiliki nilai $R$ sebesar 0.41 (Gambar 3). Hal tersebut menunjukkan korelasi yang rendah antara kecepatan tumbuh dan virulensi Colletotrichum. Isolat dengan virulensi tinggi belum tentu memiliki pertumbuhan koloni yang cepat dan isolat yang hipovirulen belum tentu pertumbuhan koloninya lambat. C. acutatum dilaporkan memiliki pertumbuhan koloni paling lambat tetapi menghasilkan diameter lesio yang besar sedangkan C. gloeosporioides memiliki pertumbuhan koloni cepat namun diameter lesio yang dihasilkan lebih kecil bahkan ada yang tidak menimbulkan gejala pada buah cabai (Than et al. 2008).

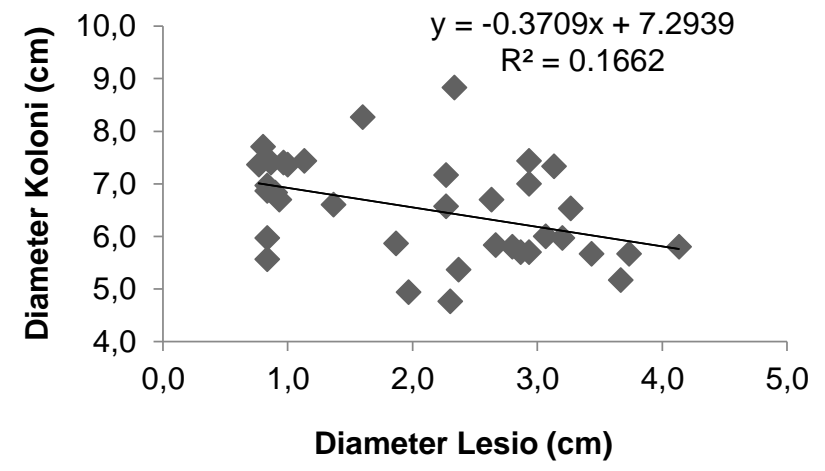

Gambar 3. Korelasi antara diameter koloni colletotrichum in vitro dan diameter lesio pada apel berdasarkan analisis regresi linear menggunakan Microsoft Office Excel 2010

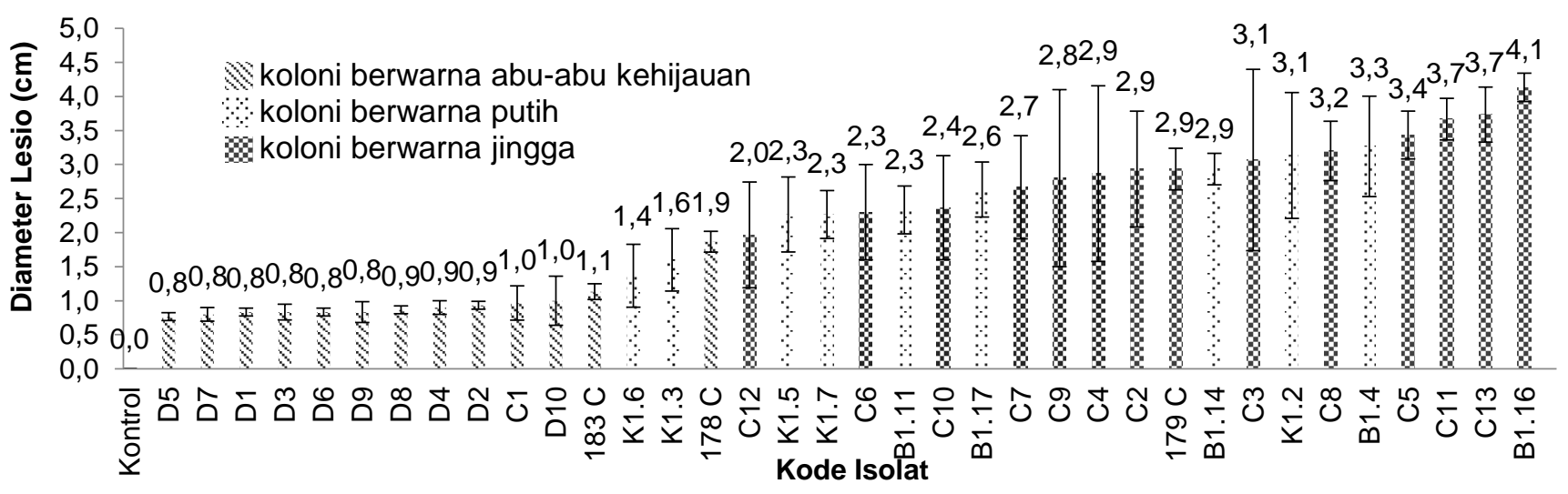

Gambar 2. Pola antara warna koloni Colletotrichum in vitro dan diameter lesio pada apel: (A) hipovirulen, (B) virulensi sedang, dan (C) virulensi tinggi 
Virulensi Colletotrichum pada buah apel bervariasi yang diukur berdasarkan ukuran diameter lesio yang dihasilkan tiap isolatnya. Lesio berupa jaringan nekrosis dengan munculnya acervuli berwarna hitam atau jingga pada beberapa isolat. Menurut Montri et al. (2009), skala virulensi untuk mengukur reaksi inang terhadap kerusakan yang disebabkan oleh patogen ditunjukkan oleh ukuran lesio serta eksistensi acervuli dan jaringan nekrosis.

Colletotrichum yang diinokulasikan pada apel memiliki tingkat virulensi beragam yang meliputi rendah, sedang, dan tinggi. Isolat dengan virulensi rendah memiliki diameter lesio antara 0.8-1.8 cm. Isolat dengan virulensi sedang memiliki kisaran diameter lesio antara 1.9-3.0 cm, sedangkan diameter lesio $>3 \mathrm{~cm}$ menunjukkan isolat dengan virulensi tinggi. Sebanyak 14 isolat yang dikategorikan bervirulensi rendah (hipovirulen) dijadikan sebagai kandidat untuk analisis RNA Total dan dua isolat dengan virulensi paling tinggi digunakan sebagai kontrol (Gambar 4).

Pemilihan kandidat didasarkan pada hipovirulensi isolat karena isolat hipovirulen berpeluang mengindikasikan adanya infeksi mikovirus yang dapat dimanfaatkan sebagai agens pengendalian hayati. Infeksi mikovirus pada jamur dapat menyebabkan efek fenotip seperti hipovirulensi atau fenomena mematikan inangnya (Sande et al. 2010). Penelitian-penelitian sebelumnya melaporkan mikovirus telah diisolasi dari strain hipovirulen. Elemen dsRNA mikovirus telah diekstraksi dari Sclerotinia sclerotiorum strain 91 yang hipovirulen (Boland 1992). Virus dsRNA bipartit baru (BpRV1) telah diisolasi dari Botrytis porri strain hipovirulen (GarlicBc-72) (Wu et al. 2012). Hubungan antara mikovirus dan hipovirulensi telah dikonfirmasi sepenuhnya dari CHV1 (Cryphonectria hypovirus 1) yang merupakan penyebab hipovirulensi pada Cryphonectria parasitica (Xie dan Jiang 2014).

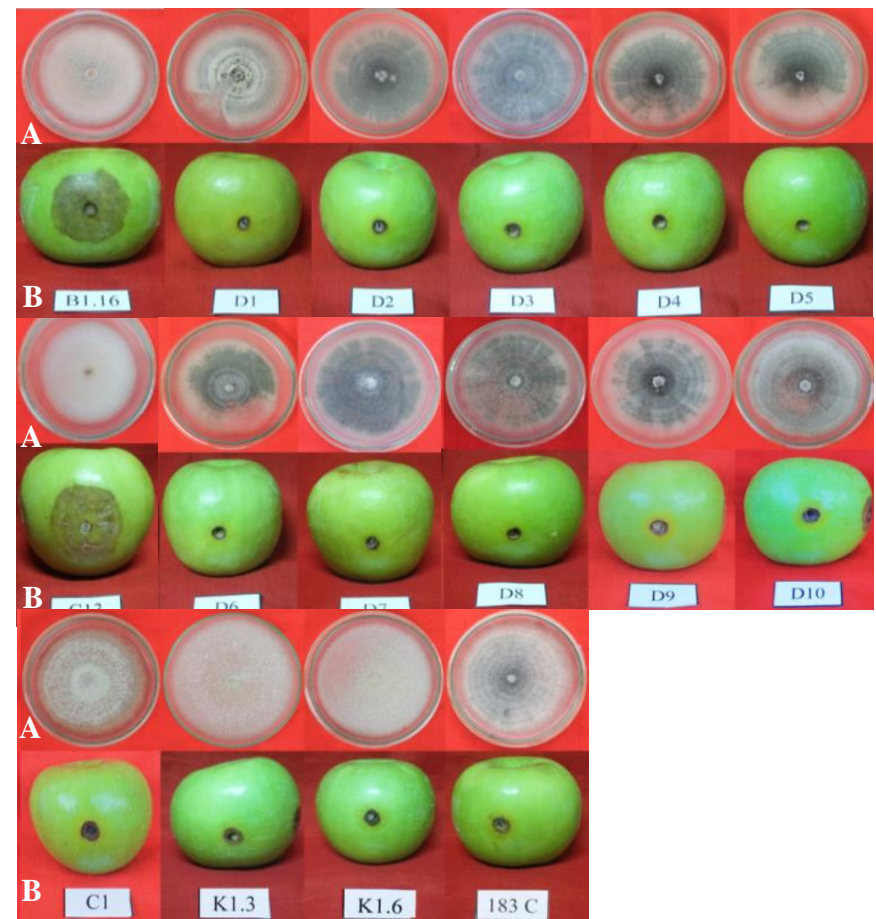

Gambar 4. Karakter koloni dan virulensi Colletotrichum: $\mathrm{B} 1.16$ dan $\mathrm{C} 13$ adalah dua isolat dengan virulensi paling tinggi; D1-D10, C1, K1.3, K1.6, 183C adalah isolat hipovirulen; (A) karakter koloni yang ditumbuhkan pada PSA selama 7 hari; (B) lesio pada apel hijau 14 hari setelah inokulasi
Analisis RNA total meliputi ekstraksi dan visualisasi RNA dari miselia Colletotrichum hipovirulen yang bertujuan untuk mendeteksi keberadaan RNA mikovirus. Pita RNA yang nampak dalam visualisasi yaitu pita ribosomal RNA (rRNA) dengan ukuran 0.9-1.5 kbp. rRNA memiliki proporsi $80-90 \%$ dari total RNA seluler sehingga muncul dan terlihat lebih jelas daripada tRNA dan mRNA ketika visualisasi (Eun 1996). mRNA tidak terlihat pada hasil visualisasi disebabkan mRNA lebih sensitif untuk terdegradasi daripada rRNA (Enke 2016), proporsi mRNA sangat rendah serta mRNA memiliki ukuran yang heterogen. Pita lain berupa pita transfer RNA (tRNA) berukuran 0.2-0.3 kbp yang berada di bagian bawah kolom pita namun tidak selalu muncul serta pita selain rRNA dan tRNA yang diduga merupakan pita RNA mikovirus.

Hasil analisis RNA total menunjukkan dari 14 isolat Colletotrichum hipovirulen terdeteksi dua isolat hipovirulen yang menunjukkan pola pita RNA spesifik. Isolat D3 menunjukkan adanya pola pita RNA spesifik dengan ukuran sekitar $3 \mathrm{kbp}$ dan 2 kbp sedangkan pita RNA spesifik isolat D9 berukuran sekitar $3 \mathrm{kbp}$ dan 0.6 kbp (Gambar 5). Pola pita RNA spesifik selain rRNA dan tRNA juga telah ditemukan pada Fusarium strain C15 dengan ukuran sekitar $1 \mathrm{kbp}$ dan $0.8 \mathrm{kbp}$ yang mengindikasikan keberadaan mikovirus (Supyani dan Widadi 2015). Genom mikovirus pada $C$. gloeosporioides dilaporkan memiliki ukuran pita dsRNA 2.63-3.397 kbp (Zhong et al. 2016) dan 0.99-2.444 kbp dsRNA pada C. camelliae (Jia et al. 2017).

Kualitas hasil visualisasi yang baik ditunjukkan dengan kenampakan pita rRNA yang tajam dan seragam. Pita D6 memiliki rRNA dengan konsentrasi rendah sehingga terlihat samar walaupun telah diekstraksi dan divisualisasi berulang kali dengan variasi jumlah dan sumber miselia. Hasil pita RNA dengan ketebalan yang bervariasi dapat disebabkan oleh perbedaan sel atau RNA yang hilang selama isolasi (Farnsworth et al. 2004).

Gambar pola pita hasil visualisasi RNA memiliki kualitas kurang baik yang ditunjukkan oleh smear pada seluruh isolat. Smear pada jalur sumuran mengindikasikan degradasi RNA oleh RNase walaupun ada upaya untuk mengurangi kontaminasi RNase (Farnsworth et al. 2004). Smear juga dapat disebabkan oleh kontaminasi genom DNA yang muncul sebagai pita dengan berat molekul tinggi atau berada di bagian atas kolom pita yang mendekati sumuran (Enke 2016).

Isolat-isolat lain yang tidak menunjukkan adanya pita spesifik RNA mikovirus kemungkinan hipovirulensinya disebabkan oleh faktor genetik. Isolat yang hipovirulen memiliki dua kemungkinan yaitu disebabkan oleh infeksi mikovirus atau hipovirulen secara genetik (Ogoshi 1987, Ghabrial 2001). Hasil ekstraksi dan visualisasi RNA ini masih perlu dikonfirmasi melalui ekstraksi dan visualisasi dsRNA untuk memastikan keberadaan mikovirus RNA. Figueiredo et al. 2012 menjelaskan bahwa kehadiran dsRNA dalam jamur dapat ditunjukkan oleh beberapa proses setelah ekstraksi dan pemurnian asam nukleat total seperti kromatografi kolom selulosa serta pemberian DNAse I dan Nuclease SI. 
Infeksi mikovirus pada jamur patogen tanaman dapat menimbulkan efek fenotip seperti menurunnya laju pertumbuhan koloni (Buck 1986, Kumar dan Chandel 2016). Pertumbuhan koloni isolat D3 dan D9 tergolong cepat yaitu masing-masing memiliki diameter koloni $7 \mathrm{~cm}$ dan $6.9 \mathrm{~cm}$ pada hari ke-7 setelah kultur. Hal ini menandakan infeksi kriptik mikovirus terhadap pertumbuhan koloni isolat D3 dan D9. Kebanyakan dsRNA dilaporkan tidak mempengaruhi perubahan pigmentasi atau morfologi koloni pada PDA (lkeda et al. 2004). Efek fenotip dari beberapa mikovirus pada inangnya tidak diketahui atau tidak mudah terlihat yang secara umum dianggap sebagai infeksi laten atau disebut infeksi kriptik (van Diepeningen et al. 2008).

\section{KESIMPULAN DAN SARAN \\ Kesimpulan}

Ditemukan pola pita RNA spesifik pada isolat Colletotrichum hipovirulen D3 dan D9 yang mengindikasikan pita RNA mikovirus. Pola pita RNA spesifik pada isolat D3 memiliki ukuran sekitar $2 \mathrm{kbp}$ dan $3 \mathrm{kbp}$ sedangkan pada isolat $\mathrm{D} 9$ berukuran $0.6 \mathrm{kbp}$ dan $3 \mathrm{kbp}$.

\section{Saran}

Penelitian lanjut untuk mengkaji transmisi serta mengkarakterisasi RNA mikovirus yang telah ditemukan perlu dilakukan sebagai rangkaian upaya pengembangan agens pengendalian hayati isolat virulen menggunakan mikovirus. Penelitian ekstraksi dan visualisasi DNA pada isolat Colletotrichum perlu dilakukan untuk mendeteksi keberadaan mikovirus dengan genom DNA.

\section{Ucapan Terima Kasih}

Penulis mengucapkan terima kasih kepada PT. Arara Abadi, Sinarmas Forestry yang telah mendanai dan menyediakan seluruh fasilitas dalam pelaksanaan penelitian ini.

\section{DAFTAR PUSTAKA}

Abera A, Lemessa F, Adunga G. 2016. Morphological characteristics of Colletotrichum species associated with mango (Mangifera indica L.) in Southwest Ethiopia. Food Sci Qual Manag 48: 106-115.

Boland GJ. 1992. Hypovirulence and double-stranded RNA in Sclerotinia sclerotiorum. Can J Plant Pathol 14: 10-17. doi: 10.1080/07060669209500900

Campo S, Gilbert KB, Carrington JC. 2016. Small RNAbased antiviral defense in the phytopathogenic fungus Colletotrichum higginsianum. PLoS Pathog 12(6): 1-36. doi: 10.1371/journal.ppat.1005640

Dickman MW. 1993. The fungi. New York (NY): Academic Press.

Enke R. 2016. Agarose gel \& spectrophotometer analysis of total RNA extractions. CSHL DNALC RNA-Seq for the Next Generation Working Group. URL:http://www.rnaseqforthenextgeneration.org/prof iles/raymond-enke.html\#teaching

Eun HM. 1996. Enzymology primer for recombinant DNA technology. San Diego (CA): Academic Press
Farnsworth R, Keating J, Mcauley M, Smith R. 2004. Optimization of a protocol for Escherichia coli RNA extraction and visualization. J Exp Microbiol Immunol (JEMI) 5: 87-94.

Figueiredo LC, Figueiredo GS, Giancoli ACH, Tanaka FAO, Silva LAO, Kitajima EW, Filho SA, Azevedo JL. 2012. Detection of isometric, dsRNA-containing viral particles in Colletotrichum gloeosporioides isolated from cashew tree. Trop Plant Pathol 37(2): 142-145. doi: 10.1590/S1982-56762012000200007

Ghabrial SA. 2001. Fungal viruses. In: O Maloy, T Murray, editors. Encyclopedia of Plant Pathology. New York (NY): John Wiley and Sons. p: 478-483.

Ghabrial SA, Caston JR, Jiang D, Nibert ML, Suzuki N. 2015. 50-plus years of fungal viruses. Virol 479-480: 356-368. doi: 10.1016/j.virol.2015.02.034

Ikeda K, Nakamura H, Arakawa M, Matsumoto N. 2004. Diversity and vertical transmission of doublestranded RNA elements in root rot pathogens of trees, Helicobasidium mompa and Rosellinia necatrix. Mycol Res 108 (6): 626-634. doi: $10.1017 /$ S0953756204000061

Jia H, Dong K, Zhou L, Wang G, Hong N, Jiang D, Xu W. 2017. A dsRNA virus with filamentous viral particles. Nat Commun 8(168): 1-12. doi: 10.1038/s41467-01700237-9

Kim WG, Hong SK, Choi HW, Lee YK. 2009. Occurrence of anthracnose on highbush blueberry caused by Colletotrichum species in Korea. Mycobiol 37(4): 310-312. doi: 10.4489/MYCO.2009.37.4.310

Kumar V, Chandel S. 2016. Mycoviruses and their role in biological control of plant diseases. Internat J Plant Sci 11(2): 375-382. doi: 10.15740/HAS/IJPS/11.2/375-382

Martinez EP, Hio JC, Osorio JA, Torres MF. 2009. Identification of Colletotrichum species causing anthracnose on Tahiti lime, tree tomato and mango. Agron Colomb 27(2): 211-218.

Montri P, Taylor PWJ, Mongkolporn O. 2009. Pathotypes of Colletotrichum capsici, the causal agent of chili anthracnose, in Thailand. Plant Dis 93(1):17-20. doi:10.1094/ PDIS-93-1-0017

Oo MM, Oh SK. 2016. Chilli anthracnose (Colletotrichum spp.) disease and its management approach. Kor $\mathrm{J}$ Agric Sci 43:153-162.

Photita W, Taylor PWJ, Ford R, Hyde KD, Lumyong S. 2005. Morphological and molecular characterization of Colletotrichum species from herbaceous plants in Thailand. Fungal Divers 18: 117-133. doi: 10.3852/09-157

Sahitya UL, Deepthi RS, Kasim DP, Suneetha P, Krishna MSR. 2014. Anthracnose, a prevalent disease in Capsicum. RJPBCS 5(3): 1583-1604.

Sakinah MAI, Suzianti IV, Latiffah Z. 2014. Phenotypic and molecular characterization of Colletotrichum species associated with anthracnose of banana 
(Musa spp) in Malaysia. Gen Mol Res 13(2): 36273637. doi: 10.4238/2014.May.9.5

Salim MA. 2012. Pengaruh antraknosa (Colletotrichum capsici dan Colletotrichum acutatum) terhadap respons ketahanan delapan belas genotipe buah cabai merah (capsicum annuum L). J ISTEK 6(1-2): 182-187.

Sande WWJ, Lo-Ten-Foe JR, Belkum A, Netea MG, Kullberg BJ, Vonk AG. 2010. Mycoviruses: future therapeutic agents of invasive fungal infections in humans?. Eur J Clin Microbiol Infect Dis 29(7): 755763. doi: 10.1007/s10096- 010-0946-7

Saxena A, Raghuwanshi R, Gupta VK, Singh HB. 2016. Chilli anthracnose: the epidemiology and management. Front Microbiol 7(1527):1-18. doi: 10.3389/fmicb.2016.01527

Sharma M, Kulshrestha S. 2015. Morphological and pathogenicity assay of Colletotrichum gloeosporioides - an anthracnose causing pathogen of fruits and vegetables. Int J Agric Sci Res 5(4): 131 138.

Soesanto L. 2013. Pengantar pengendalian hayati penyakit tanaman. Jakarta (ID): PT. Raja Grafindo Persada.

Supyani. 2017. Mikovirus, pengembangannya sebagai agens pengendali hayati. JPTI 21(1): 1-9. doi: 10.22146/jpti.17874

Supyani, Widadi S. 2015. Hypovirulent isolates of Fusarium collected from chili crops in Boyolali Regency, Central Java, Indonesia. Agrivita 37(1): 6774. doi: 10.17503/Agrivita-2015-37-1-p067-074

Than PP, Jeewon R, Hyde KD, Pongsupasamit S, Mongkolporn O, Taylor PWJ. 2008. Characterization and pathogenicity of Colletotrichum species associated with anthracnose on chilli (Capsicum spp.) in Thailand. Plant Pathol 57: 562-572. doi: 10.1111/j.1365-3059.2007.01782.x

Thu PQ, Griffiths MW, Pegg GS, McDonald JM, Wylie FR, King J, Lawson SA. 2010. Healthy plantations: a field guide to pests and pathogens of Acacia, Eucalyptus and Pinus in Vietnam. Queensland (AU): Department of Employment, Economic Development and Innovation.

Wang S, Ongena M, Qiu D, Guo L. 2017. Fungal viruses: Promising fundamental research and biological control agents of fungi. SM Virol 2(1):1-5.

Weir BS, Johnston PR, Damm U. 2012. The Colletotrichum gloeosporioides species complex. Stud Mycol 73: 115-180. doi: 10.3114/sim0011

Wu M, Jin F, Zhang J, Yang L, Jiang D, Li G. 2012. Characterization of a novel bipartite double-stranded RNA mycovirus conferring hypovirulence in the pathogenic fungus Botrytis porri. J Virol 86 (12):6605-6619. doi:10.1128/JVI.00292-12

Xie J, Jiang D. 2014. New insights into mycoviruses and exploration for the biological control of crop fungal diseases. Annu Rev Phytopathol 52(3): 1-24. doi: 10.1146/annurev-phyto-102313-050222

Yu X, Li B, Fu Y, Xie J, Cheng J, Ghabrial SA, Li G, Yi X, Jiang D. 2013. Extracellular transmission of a DNA mycovirus and its use as a natural fungicide. Proc Natl Acad Sci USA 110(4):1452-1457. doi: 10.1073/pnas. 1213755110

Zhong J, Pang XD, Zhu HJ, Gao BD, Huang WK, Zhou Q. 2016. Molecular characterization of a trisegmented mycovirus from the plant pathogenic fungus Colletotrichum gloeosporioides. Viruses 8(10): 1-12. doi:10.3390/v8100268 